\author{
(online) $=$ ISSN $2285-3642$ \\ ISSN-L = 2285 - 3642 \\ Journal of Economic Development, Environment and People \\ Volume 4, Issue 4, 2015 \\ URL: $\underline{\text { http://jedep.spiruharet.ro }}$ \\ e-mail: office jedep@spiruharet.ro
}

\title{
Public Debts Trends in the Current Economic Context, from Both National and International Perspective ${ }^{1}$
}

\author{
Elena-Doina DASCĂLU, Dragoș Mihai UNGUREANU \\ Spiru Haret University, Faculty of Economics, 46 G Fabricii Str., District 6, Bucharest, \\ Phone: 021 3169785, Email: doina.dascalu@rcc.ro, dragos.ungureanu@yahoo.com
}

\begin{abstract}
The article presents an analysis of the way public debt operates in Romania, in the context of states economies trends, of complex and topical financial environments.

In the context of a functional market economy, the issues faced by certain states involving high public debt levels or potential budgetary pressure risks converge towards the idea that public finances sustainability needs to be a major challenge at the level of public policies.

Considering this situation, the adequate policies to tackle public finances sustainability need to have, as a launching base, the overall strategy of the European Union, focused on the three component parts, namely abatement of public debt, increasing productivity and employment and last but not least, reforming the pension and healthcare systems.

To ensure reasonably sustainable public debt levels, EU member states need to attain medium term strategic budgetary objectives, that would ensure a downward trend of public debt, a condition which can be fulfilled by compliance with budget policies rules, which ground development in the macroeconomic framework.
\end{abstract}

Keywords: public debt, state loan, public debt sustainability, vulnerability, budget deficit, gross domestic product (GDP), indebtedness, the European Accounts System, Maastricht Treaty etc.

JEL Codes: E60, E61, H60, H61

\section{Current economic context of public debt}

The financial crises at global level during the latest 25 years resulted in the negative impacting of governments' capacity to reimburse accumulated debt, which triggered both budget difficulties and economic disturbances.

At European and world level, financial stability is upset by the alarming increase of states' debts. Thus, as compared to 2007 , the year of the previous world financial crisis, at the end of 2014, debts at global level

\footnotetext{
${ }^{1}$ The article was previous presented at International Conference on Economic Sciences and Business Administration 2015
} 


\author{
(online) $=$ ISSN $2285-3642$ \\ ISSN-L = 2285- 3642 \\ Journal of Economic Development, Environment and People \\ Volume 4, Issue 4, 2015 \\ URL: http://jedep.spiruharet.ro \\ e-mail: office jedep@spiruharet.ro
}

increased by 57,000 billion dollars, reaching a level close to 200,000 billion dollars. ${ }^{2}$ The debts increase rhythm exceeds that of the world economicic enhancement. Thus, in keeping with the information published by the Financial Times ${ }^{3}$, debts exploded, in relation to global economy, from $270 \%$ of the GDP to $286 \%$ of the GDP, which means that, at world level, it is owed three times more than it is produced.

Public debt managers operate nowadays in sophisticated and complex financial environments, and a global capital market can generate numerous benefits (for example, easier access to a larger capital portfolio at a lower cost, more effective internal capital markets and the possibility to better adapt risk through new financial instruments). Nevertheless, public debt strategies may become dangerously vulnerable when confronted with unforeseen events, such as private sector balance deterioration, which can result in taxation, financial and economic crises.

Economic shocks may have, individually or cumulatively, an impact on external public debt of an economy, which leads to the vulnerability of the public debt strategy, which in turn may impact on global economy and, last but not least, may seriously deteriorate a state's financial situation. Recent examples taken from emerging economies showed that shocks may turn into financial crises, which can make public management difficult and have significant budgetary consequences.

In this context, states' needs are covered, to the greatest extent, from taxes, fees, contributions, takeoffs, which the state collects from tax payers. In many instances, this kind of resources (ordinary ones) are insufficient and then, both the state and the local collectivities are made to approach a different type of financial resources, known as extraordinary ones, that is public loans.

In any economy, this type of loan is tackled to cover the so-called 'cash deficit', which appears in the operation of a tax system, respectively the failure to timely collect the income which was supposed to be cashed at the budget, as well as the need to make expenses falling due. In the instance of an operational market economy, the state uses this financing source to promote new investments, meant for modernisation, as well as for innovation of existing assets, a context in which the public debt notion emerges.

One of the basic principles of state budget establishment (as of any kind of budget, for that matter) is the budgetary balance, but this is not obtained, most of the times, automatically, by covering budget expenditures with budget revenues, in such situations we say the budget is established with a financing deficit, ${ }^{4}$ called budgeting deficit.

\footnotetext{
${ }^{2}$ Ministry of Public Finances - Assessment of Public Debt Management, in the Period 2012 - 2014 , at the www.curteadeconturi.ro/

${ }^{3}$ Financial Times, http://www.ft.com/home/uk

${ }^{4}$ Gheorghe D. Bistriceanu, Lexicon de finanţe-bănci-asigurări (Finances-banks-insurances Lexicon), Vol. II, Editura Economică, Bucharest, 2001
} 


\author{
(online) $=$ ISSN $2285-3642$ \\ ISSN-L = 2285- 3642 \\ Journal of Economic Development, Environment and People \\ Volume 4, Issue 4, 2015 \\ URL: $\underline{\text { http://jedep.spiruharet.ro }}$ \\ e-mail: office jedep@spiruharet.ro
}

Both state budget deficit and public debt of the state are established in a rather wide sense and without considering all influence factors which can modify their size during budget execution ${ }^{5}$.

In our country, the concept of public debt was reconsidered in relation to the new realities and transformations having emerged after the events of December 1989, which created the social and institutional framework required for the development of a market economy. Up to now, the public debt notion went through the following defining process ${ }^{6}$ :

$>$ public debt represents "the overall pecuniary obligations, at a given moment, resulting from internal and external loans, on medium or long term, contracted by the state on its own behalf or guaranteed by the latter");

$>$ public debt represents "the overall state internal and external obligations, at a given moment, contracted by the Government, through the intermediary of the Ministry of Finances, on behalf of Romania";

public debt represents "the government public debt to which local public debt is added"

public debt represents "the overall obligations falling into the category of government and local public debt ${ }^{10 \prime "}$.

However, as different from the public debt notion established based on national legal provisions, in the European legislation ${ }^{11}$ public debt is defined as being "... the overall gross debts due at the end of the year, at their nominal value, in the public administration sector, except for the liabilities the financial assets of which are held by the public administration sector. Public debt is made of the central administration' liabilities and includes the following categories: cash and deposits, securities other than shares, except for derivatives and credits, as defined in ESA95 ${ }^{12 "}$.

\footnotetext{
${ }^{5}$ Dascălu D., Ungureanu M.D., Considerations regarding the analyses of public debt in the current economic context, both national and international level, International Conference on Economic Sciences and Business Administration, 2021 noiembrie 2015

${ }^{6}$ Assessment of public debt management, www.curteadeconturi.ro

${ }^{7}$ Law no. 81/1999 on public debt, published in the Official Journal no. 215 of May 17, 1999;

${ }^{8}$ Law no. 91/1993 on public debt, published in the Official Journal no. 3 of January 10, 1994

${ }^{9}$ Law no. 313/2004 on public debt, published in the Official Journal no. 577 of June 29, 2004;

${ }^{10}$ Government Emergency Ordinance no. 64/2007 on public debt, published in the Official Journal, Part I no. 439, of June 29, 2007.

${ }^{11}$ Council Regulation (EC) No 479/2009 of 25 May 2009 on the application of the Protocol on the excessive deficit procedure appended to the Treaty establishing the European Community, re-issued;

${ }^{12}$ ESA is the acronym of European System of Accounts, according to EUROSTAT - The European Statistics Institute
} 


\author{
(online) $=$ ISSN $2285-3642$ \\ ISSN-L = 2285-3642 \\ Journal of Economic Development, Environment and People \\ Volume 4, Issue 4, 2015 \\ URL: $\underline{\text { http://jedep.spiruharet.ro }}$ \\ e-mail: office jedep@spiruharet.ro
}

The state loan is a defining element of public debt, as provided in the specialised literature and in the legal texts. as a conclusion, it can be said that the" state loan" notion is considered to be the material result of an agreement made in writing, concluded by the state through its financial agent with a moral or legal entity, to mobilise from them money availabilities, for a definite period of time, under a priori provided reimbursement and interest conditions.

It is important to mention that engaging public debt involves a series of risks, generated both by general and by specific factors ${ }^{13}$. Among general factors acting in the financial domain, the special regulations providing different conditions for certain loans are extremely important. Another series of general risk factors is that of the highly complex issues, which may emerge in the unfold of current processes.

Furthermore, the special conjunctures on international financial markets may negatively impact on state loans contracting conditions.

Structural factors may be, in certain instances, risk generators when the public debt management system component parts are not sufficiently regulated.

Specific risk factors in the field of public debt refer to the conditions in which a certain loan is contracted or to the decision that the state guarantees a certain loan. The decision to make a sub-loan involves recovery risks. The foreign exchange risk is another relevant issue, which needs to be considered when concluding a foreign currency loan, whether this is conducted on the domestic or the external capital market.

Inflationist phenomena, known as factors eroding public debt, also have a negative influence on budgets, especially in the instance of external public debt, since their effects impact stronger on nonconvertible currency than on convertible ones.

\title{
2. Considerations on public debt sustainability
}

The current applicable Romanian legislation provides that ${ }^{14},{ }^{\prime \prime} . .$. the Ministry of Public Finances fulfils the strategy functions, providing for the establishment of the strategy in the field of public debt and the public debt management function" and its main competences are contracting and reimbursing public debt and managing the risks pertaining to government public debt portfolio, establishing the documents on the state public debt annual general account, which they submit to the Government for information purposes, in view of tabling for adoption in the Parliament, contracting and guaranteeing of state loans on the internal and external financial market, for the aim and within the competences provided by law, as well as the supervision of the compliance with the engagements concluded with international financial bodies in the field of public debt.

\footnotetext{
${ }^{13}$ Dascălu D., Datoria publică, reglementări și administrare in România (Public Debt, Regulations and Management in Romania), Editura Didactică și Pedagogică RA, Bucharest, 2008

${ }^{14}$ Government Decision no. 34/2009 on the Organisation and Operation of the Ministry of Public Finances, published in the Official Journal no. 52 of 28.01.2009, as subsequently modified and completed.
} 


\author{
(online) = ISSN $2285-3642$ \\ ISSN-L = 2285- 3642 \\ Journal of Economic Development, Environment and People \\ Volume 4, Issue 4, 2015 \\ URL: $\underline{\text { http://jedep.spiruharet.ro }}$ \\ e-mail: office jedep@spiruharet.ro
}

Furthermore, legal provisions ${ }^{15}$ established certain principles grounding the implementation of an efficient management of public finances, respectively of the public debt which would serve long term public interest, of an economic prosperity, as well as to anchor fiscal-budgetary policies in a sustainable framework. In this context, national institutions having competences in this field are under the obligation to prudently conduct the fiscal-budgetary policy and to manage budgetary resources and liabilities, as well as the fiscal risks so as to grant the sustainability of the fiscal position, on medium and long term.

Public finances sustainability, from this perspective ${ }^{16}$, involves Government being able to manage, in the medium and long run, risks or unforeseen situations, without being forced to operate significant adjustments of the expenditures, revenues or budgetary deficits, with destabilising effects from the economic and social point of view.

The concept of public finances is associated, in the specialised literature ${ }^{17}$, with "the state, the administrative and territorial units and with other public law institutions, in relation with the resources, expenditures, loans and the pertaining debt." Public finances ${ }^{18}$ are defined as "the public finances science dealing with the study of facts, principles, techniques and effects of acquiring and spending funds by government and public debt management bodies."

Moreover, in keeping with studies in the field of public finances and taxation, "... public finances represent a research domain dealing with the issues concerning revenues and expenditures of governments (federal, state and local ones). In modern times, these issues are divided into four large categories: public revenue, public expenditure, public debt and certain issues of the taxation system as a whole, such as local administration and taxation policy ${ }^{19 \prime}$.

From the analysis of the above, there results that public debt sustainability is a concept inter-relating with public finances sustainability. Thus, it can be concluded that "... public debt sustainability represents

\footnotetext{
${ }^{15}$ Law no. 69/2010 on Fiscal and Budgetary Accountability, published in the Official Journal no. 252 of April 20, 2010, updated in 2015.

${ }^{16}$ Dascălu D., Ungureanu M.D., Considerations regarding the analyses of public debt in the current economic context, both national and international level, International Conference on Economic Sciences and Business Administration, 2021 noiembrie 2015

${ }^{17}$ Iulian Văcărel et al, Finanţe publice (Public Finances), second edition, Editura Didactică şi Pedagogică - Bucharest, 2008

${ }^{18}$ William J. Shultz şi C. Lowell Harriss, American Public Finance, sixth edition, New York, 1954.

${ }^{19}$ Harold M. Groves, Financing Government, sixth edition, Holt, Rinehart and Winston, New York, Chicago, San Francisco, 1964.
} 


\author{
(online) $=$ ISSN $2285-3642$ \\ ISSN-L = $2285-3642$ \\ Journal of Economic Development, Environment and People \\ Volume 4, Issue 4, 2015 \\ URL: $\underline{\text { http://jedep.spiruharet.ro }}$ \\ e-mail: office jedep@spiruharet.ro
}

the extent to which a government can maintain existing programmes and can fulfil creditors' requirements without increasing public debt burden on the economy ${ }^{20 "}$.

The Romanian economy, as a component part of world economy, displays the same trends, respectively an increase of public debt in a rhythm superior to the economic growth one, so that public finances sustainability needs to be a major challenge at the level of public policies ${ }^{21}$.

Adequate policies to tackle public finances sustainability challenges need to be grounded in the overall EU strategy (focussed on the three component parts, namely, abatement of public debt, increase of productivity and of employment and reform of pensions and healthcare systems) and the main causes of the problems relating to public finances sustainability confronting various member states. To ensure sustainable levels of public debt it is important that EU member states understand certain medium term budgetary objectives, which would result in a descending trend of public debt, through strict compliance with budgetary policy ${ }^{22}$.

\title{
3. Analysis of public debt sustainability
}

The analysis of public debt sustainability is meant to offer answers and solutions relating to the capacity of a government to maintain the same direction of expenditures and revenues or, in case they have to make an adjustment, to turn government public debt constant as a proportion of the GDP.

Thus, the analysis of public debt sustainability is a complex exercise, with multiple implications and which needs to consider the following ${ }^{23}$ :

- the trend of the public debt indicator in relation to the gross domestic product (GDP);

- the indicator public debt related to GDP, which is consolidated at a high level, but with an acceptable re-financing risk and with the preservation of the economic growth tendency;

- the structure of public debt which may increase the probability that negative circumstances emerge relating to it.

\footnotetext{
${ }^{20}$ ISSAI [The International Standards of Supreme Audit Institutions] 5410 "Guidance for Planninng and Conducting an Audit of Internal Controls of Public Debt".

21 Assessment of public debt management in the period 2012 - 2014 at the Ministry of Public Finances" www.curteadeconturi.ro/

${ }^{22}$ Assessment of public debt management in the period 2012 - 2014 at the Ministry of Public Finances www.curteadeconturi.ro/
}

${ }^{23}$ Dascălu D., Ungureanu M.D., Considerations regarding the analyses of public debt in the current economic context, both national and international level, International Conference on Economic Sciences and Business Administration, 2021 noiembrie 2015 


\author{
(online) $=$ ISSN $2285-3642$ \\ ISSN-L = 2285 - 3642 \\ Journal of Economic Development, Environment and People \\ Volume 4, Issue 4, 2015 \\ URL: http://jedep.spiruharet.ro \\ e-mail: office jedep@spiruharet.ro
}

The following chart is an illustration of the public debt level evolution, of the Romanian GDP, in the period 31.12.1990-31.12.2014 ${ }^{24}$ :

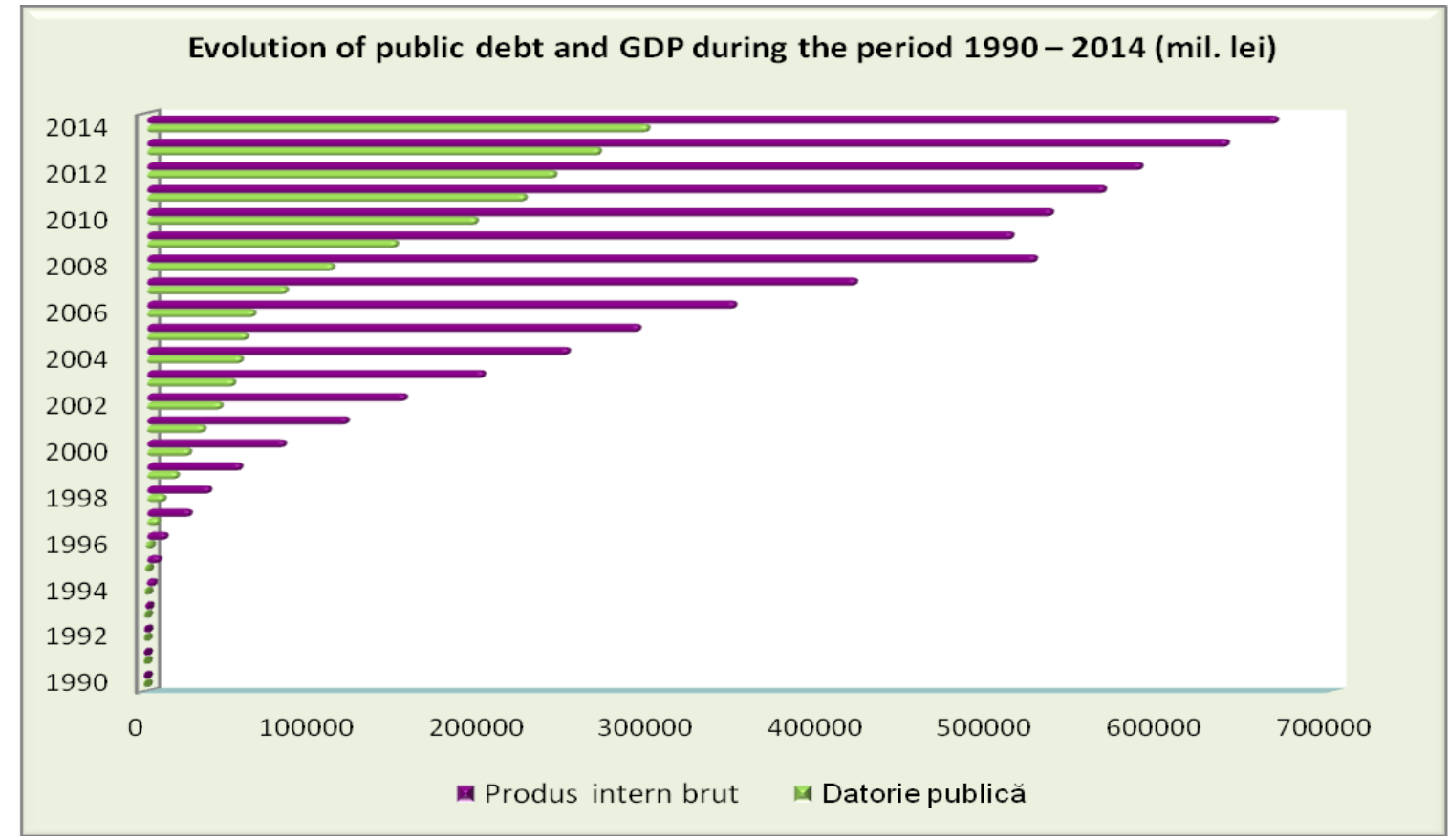

Figure 1: public debt and GDP evolution, in the period 1990 - 2014 (in million lei)

Source: data published by the National Statistics Institute, www.insse.ro

The analysis of this data shows that in 2014, as compared to 1990, public debt went up in a rhythm superior to the economic growth one, a situation in which public finances sustainability needs to be a major challenge at the level of public policies.

The public debt/GDP indicator is the most used one and measures the indebtedness level in relation with the economic activity of the country, being acknowledged as the most important one in measuring indebtedness, as it highlights the country's credit-worthiness.

The ratio between state public debt and GDP, one of the convergence criteria established based on the Protocol on the excessive deficit procedure appended to the Maastricht Treaty ${ }^{25}$, shows that this has been significantly lower than the value of $60 \%$ of the GDP.

The evolution of public debt percent of the GDP indicator for the period $1990-2014^{26}$ is shown in the following chart, as follows:

\footnotetext{
${ }^{24}$ Source: data published by the National Statistics Institute, www.insse.ro

${ }^{25}$ Treaty of the European Union, published in the Official Journal C191 of July 29, 1992

${ }^{26}$ Source: data published by the National Statistics Institute, www.insse.ro
} 


$$
\begin{gathered}
\text { (online) }=\text { ISSN } 2285-3642 \\
\text { ISSN-L = 2285 - 3642 } \\
\text { Journal of Economic Development, Environment and People } \\
\text { Volume 4, Issue 4, } 2015 \\
\text { URL: } \underline{\text { http://jedep.spiruharet.ro }} \\
\text { e-mail: } \underline{\text { office jedep@spiruharet.ro }}
\end{gathered}
$$

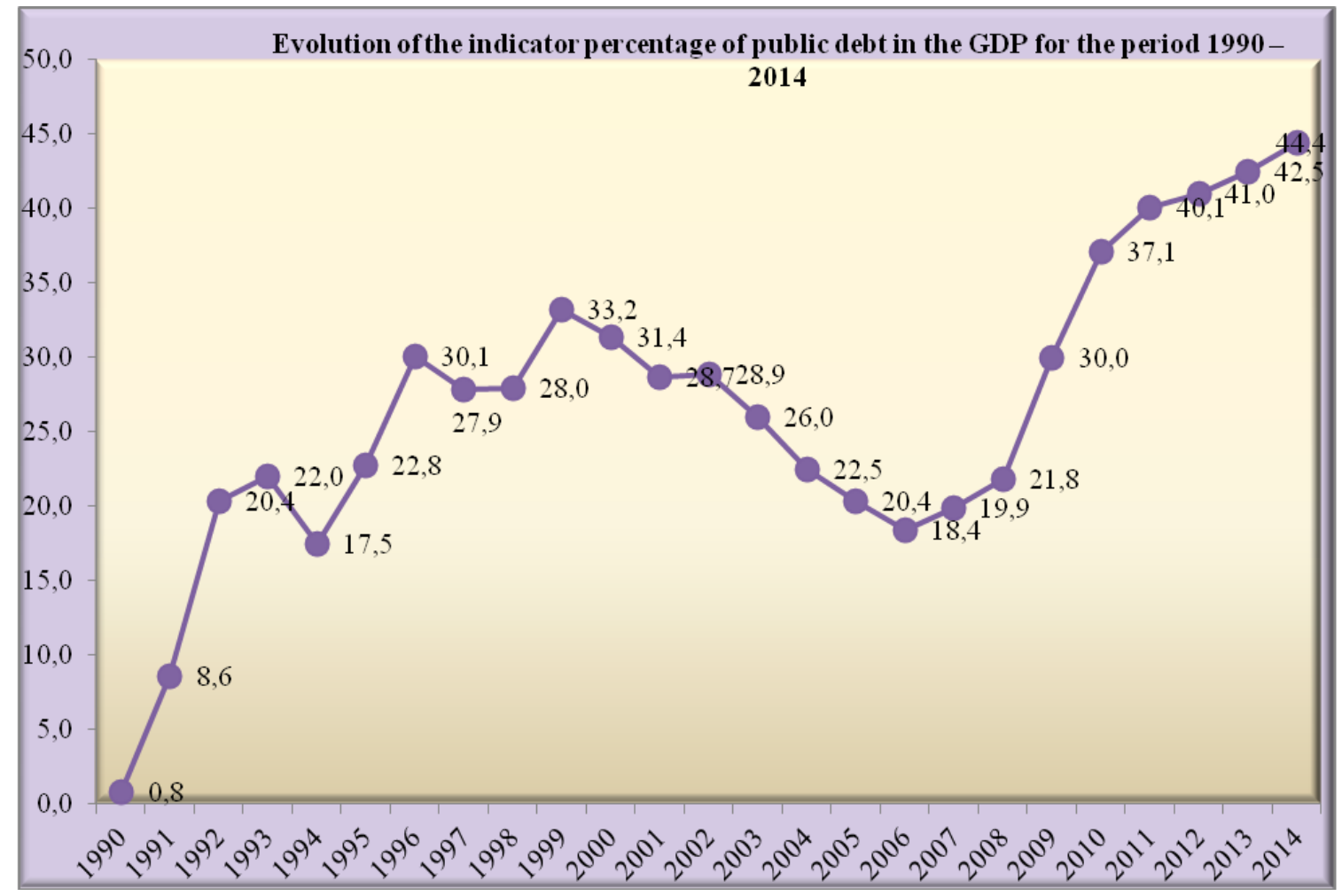

Figure 2: The evolution of public debt percent of the GDP indicator for the period $1990-2014$, Source: data published by the National Statistics Institute, www.insse.ro

The National Bank of Romania (the Directorate for Financial Stability) highlights that for sustainability reasons within the emerging economies group, as well as to moderate expenditure involved by interest and their impact on the primary deficit, the taxation consolidation process should limit the public debt level at values under $40 \%$ of the GDP ${ }^{27}$.

Even if the ratio between public debt and the gross domestic product is under the $60 \%$ warning threshold, it is considered that, given that public debt increase rhythm is higher than the economic growth rhythm, there is a possibility that the credit-worthiness risk undergoes an increase which may negatively impact the macro-economic ensemble.

Furthermore, it can be seen that certain significant increases of this indicator were also recorded in 1996, respectively $30.1 \%$ and in 1999 - 33.2\%, after which a downward trend emerged until 2006, when it

\footnotetext{
${ }^{27}$ According to the Report on Financial Stability 2012, drafted by the National Bank of Romania - the Directorate for Financial Stability
} 


\author{
(online) $=$ ISSN $2285-3642$ \\ ISSN-L = 2285- 3642 \\ Journal of Economic Development, Environment and People \\ Volume 4, Issue 4, 2015 \\ URL: $\underline{\text { http://jedep.spiruharet.ro }}$ \\ e-mail: office jedep@spiruharet.ro
}

reached the level of $18.4 \%$. After 2007, the weight of the public debt in the GDP had an upward trend, reaching the maximum $44.4 \%$ in 2014.

The evolution of the indebtedness at UE member states level ${ }^{28}$, for the period 2012-2014 is further presented, in order to offer an overall image and to be in a position to assess the stage reached by Romania, as follows:

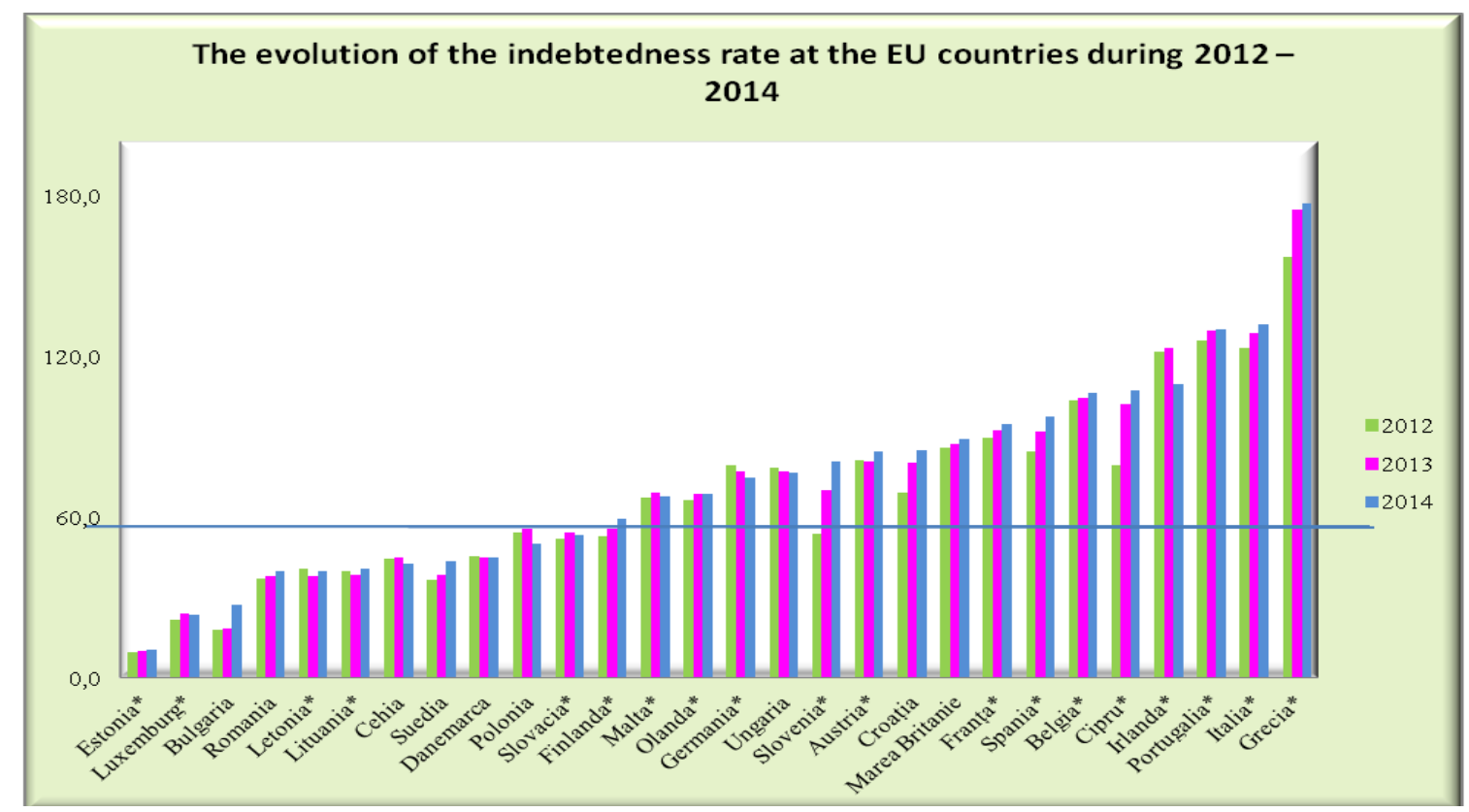

Figure 3: The evolution of indebtedness of EU member states, in the period $2012-2014$ Source: http://ec.europa.eu/eurostat/documents

*member states which adopted euro as a national currency

The analysis of the above-mentioned data shows that, even if the indebtedness of Romania continues to be lower than the indebtedness of other European national economies, its tendency to accelerate is worrying, which makes it necessary to analyse sustainability of public debt and of budget deficits.

As of its accession to the European Union, Romania had one of the lowest public debt level within the EU (19.9\% of the GDP in 2007 and $\mathbf{2 1 . 8 \%}$ in 2008). The period 2009-2011, characterised by higher budgetary deficits, practically lead to the doubling of the public debt.

Public debt, as results from the calculation made based on the EUROSTAT methodology stabilised only after 2014, reaching a $\mathbf{3 9 . 8}$ level, which positions it much below the European average and within the ceilings accepted according to nominal convergence criteria.

${ }^{28}$ http://ec.europa.eu/eurostat/documents 


\author{
(online) = ISSN $2285-3642$ \\ ISSN-L = $2285-3642$ \\ Journal of Economic Development, Environment and People \\ Volume 4, Issue 4, 2015 \\ URL: http://jedep.spiruharet.ro \\ e-mail: office jedep@spiruharet.ro
}

According to the data listed by EUROSTAT ${ }^{29}$, in the period $2012-2014$, the average level of public debt within EU28 $8^{30}$ had an upward trend, from 11,227,119 million euro to 12,094,614 million euro, respectively an increase by $\mathbf{7 . 7 3 \%}$. The level of the GDP within the EU28 had a similar, but less abrupt tendency, which only went up by $3.81 \%$, from $13,420,148$ million euro to $13,931,719$ million euro.

Thus, the public debt increase rhythm, at the level of the EU28, exceeded the economic growth rhythm. The average ratio between the public debt and the GDP increased within the EU28 from $\mathbf{8 3 . 7 \%}$ in 2012 to $\mathbf{8 6 . 8 \%}$ in $\mathbf{2 0 1 4}$, a level exceeding by much the limit of $\mathbf{6 0 \%}$ of the GDP provided in the Maastricht Treaty $^{31}$.

As it can be seen, in the analysed period, 16 of the 28 member states of the EU28 exceeded the reference value of public debt - 60\% of the GDP, set by the Maastricht Treaty, respectively Greece, Italy, Portugal, Ireland, Cyprus, Belgium, Spain, France, Great Britain, Croatia, Austria, Slovenia, Hungary, Germany, the Netherlands, Malta.

The relation between the GDP and budgetary deficit highlights to what extent economic development is sustainable, from the perspective of resources and debts.

The evolution of the ratio between the deficit and the GDP, in keeping with the data taken over from EUROSTAT ${ }^{32}$, for the period $2012-2014$, in the European member states is shown graphically, as follows:

The data in figure 4 show that the highest deficits in relation to the GDP were recorded in 2013 by Slovenia and Greece. The countries with the highest budget excedents were Denmark (in 2014) and Luxembourg (in 2013). Furthermore, two member states had budget excedents on the overall analysed period, respectively Germany (with a peak in 2014) and Luxembourg (with a peak in 2013). In the period 2012 - 2014, Germany had budget excedents when at the same time its indebtedness exceeded the threshold of $\mathbf{6 0 \%}$ of the GDP $(\mathbf{7 9 . 3} \%, \mathbf{7 7 . 1 \%}$ and respectively $\mathbf{7 4 . 7 \%}$ of the GDP).

In 2014, the deficit exceeded $\mathbf{- 3 . 0} \%$ of the GDP in 12 EU member states, respectively: the highest public deficits (as percent of the GDP) were found in Cyprus, Spain, Croatia and the United Kingdom, while Italy was at the ceiling of $-3.0 \%$ of the GDP. Among these, 10 states had deficits exceeding $\mathbf{3 . 0 \%}$ during each of the three previous years, that is for the overall analysed period.

\footnotetext{
${ }^{29}$ EUROSTAT - the European Union institution for statistics - Publication "The Euro area and EU 28 government deficit at $2.4 \%$ and $2.9 \%$ of GDP respectively, Government debt at $91.9 \%$ and $86.8 \% "$ of April 21,2015

${ }^{30} \mathrm{EU} 28=$ The European Union made of the 28 member states.

${ }^{31}$ Maastricht Treaty on the European Union, http://eur-lex.europa.eu/

${ }^{32}$ EUROSTAT - The European Statistics Institute
} 


$$
\begin{gathered}
\text { (online) }=\text { ISSN } 2285-3642 \\
\text { ISSN-L = 2285 - 3642 } \\
\text { Journal of Economic Development, Environment and People } \\
\text { Volume 4, Issue 4, } 2015 \\
\text { URL: } \underline{\text { http://jedep.spiruharet.ro }} \\
\text { e-mail: } \underline{\text { office jedep@spiruharet.ro }}
\end{gathered}
$$

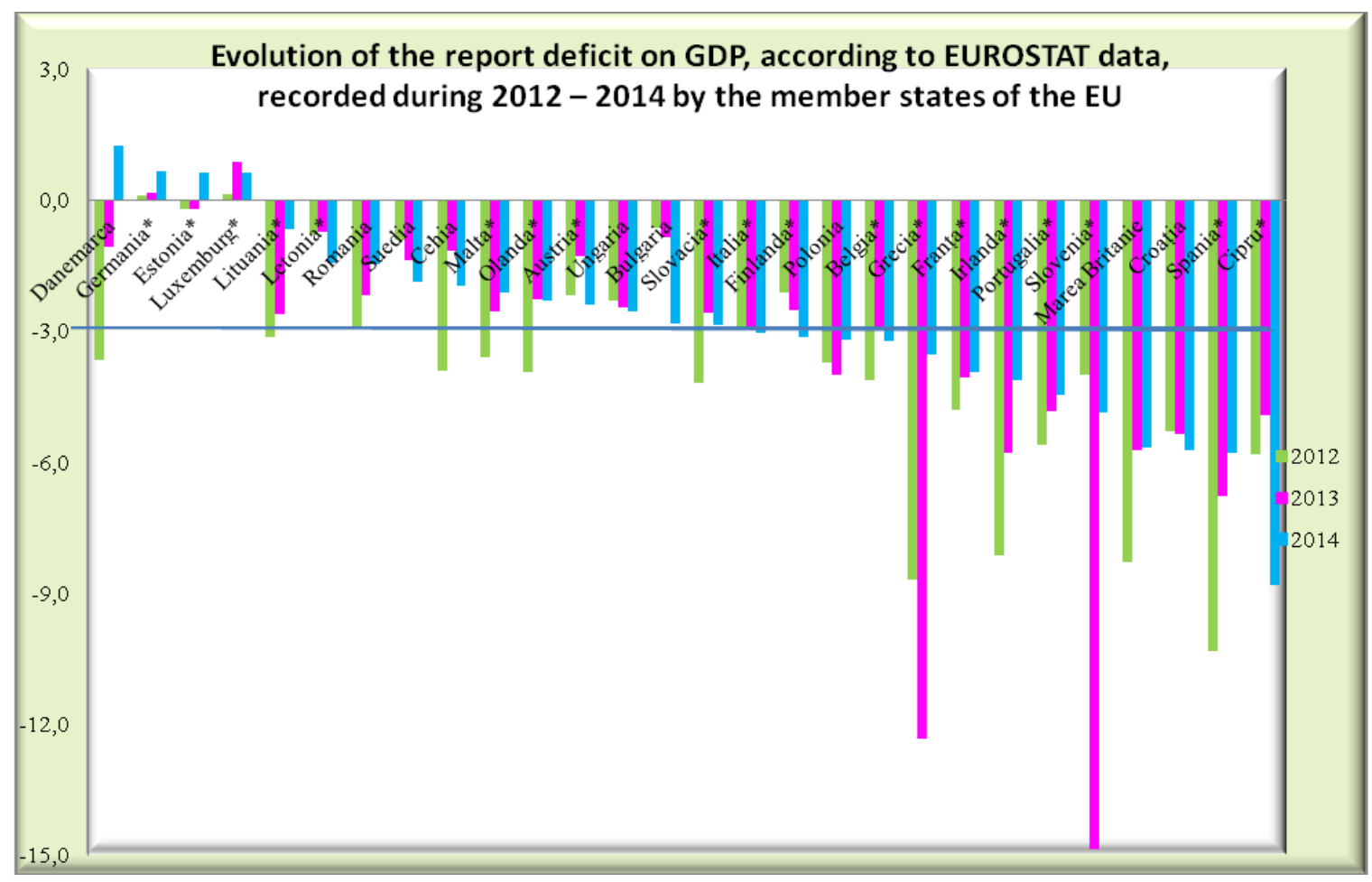

Figure 4: Evolution of the ratio between the deficit and the GDP in EU member states, in the period $2012-2014$ Source: EUROSTAT, http://eur-lex.europa.eu/

As compared to 2013, public deficit in relation to the GDP decreased in 2014 in 10 member states, the Netherlands and the United Kingdom had the same deficits in 2014 as in 2013, Estonia and Denmark switched from a deficit in 2013 to an excedent in 2014, Germany recorded a little higher excedent in 2014 than in 2013, while the excedent of Luxembourg had slightly decreased from 2013 until 2014. The other 12 EU member states had higher deficits in 2014 as compared to 2013.

Considering the above-mentioned analyses, it can be concluded that the public deficit indicator related to the gross domestic product of our country, having a level of 1.5\%, calculated according to the ESA $2010^{33}$, sets us on the 7th place among the $\mathbf{2 8}$ member states, respectively on the 3rd place among the 24 countries which recorded a deficit.

The analysis of the extent to which the criteria set by the Maastricht Treaty relating to sustainability have been complied with is dependent on reaching a high actual convergence level, the level of the GDP/inhabitant being the most synthetic indicator in this respect.

\footnotetext{
${ }^{33}$ ESA 2010 - The European System of Accounts, the 2010 issue, established by EUROSTAT
} 


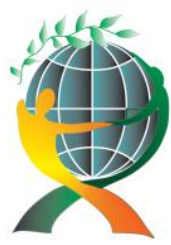

\author{
(online) = ISSN $2285-3642$ \\ ISSN-L = 2285- 3642 \\ Journal of Economic Development, Environment and People \\ Volume 4, Issue 4, 2015 \\ URL: http://jedep.spiruharet.ro \\ e-mail: office jedep@spiruharet.ro
}

The evolution of public debt in Romania/inhabitant and of the GDP/inhabitant, in the period 19902014 is as follows:

\begin{tabular}{|c|c|c|c|c|c|c|c|c|c|}
\hline Year & $\begin{array}{l}\text { Public Debt } \\
\text { (mil. lei) }\end{array}$ & $\begin{array}{l}\text { Public Debt } \\
\text { (mil. euro*) }\end{array}$ & $\begin{array}{l}\text { GDP } \\
\text { (mil. lei) }\end{array}$ & $\begin{array}{l}\text { GDP } \\
\text { (mil. euro*) }\end{array}$ & $\begin{array}{l}\text { Population of } \\
\text { Romania } \\
\text { (mil. } \\
\text { inhabitants) }\end{array}$ & $\begin{array}{l}\text { Public Debt } \\
\text { lei/ } \\
\text { inhabitant }\end{array}$ & $\begin{array}{l}\text { Public Debt } \\
\text { euro/ } \\
\text { inhabitant }\end{array}$ & $\begin{array}{l}\text { GDP } \\
\text { lei/ } \\
\text { inhabitant }\end{array}$ & $\begin{array}{l}\text { GDP } \\
\text { euro/ } \\
\text { inhabitant }\end{array}$ \\
\hline $0 \quad 1$ & 1 & 3 & 2 & 3 & 4 & $5=1 / 4$ & $6=3 / 4$ & $5=1 / 4$ & $6=3 / 4$ \\
\hline 1990 & 0.7 & $7 x$ & 85.8 & $\mathrm{x}$ & 23.21 & 0.03 & $3 x$ & 3.7 & $x$ \\
\hline 1991 & 19.0 & $x$ & 220.4 & $x$ & 23.19 & 0.82 & $x$ & 9.5 & $x$ \\
\hline 1992 & 123.3 & $x$ & 602.9 & $x$ & 22.79 & 5.41 & $x$ & 26.5 & $x$ \\
\hline 1993 & 439.8 & $x$ & $2,003.6$ & $x$ & 22.76 & 19.33 & $x$ & 88.0 & $x$ \\
\hline 1994 & 873.3 & $x$ & $4,979.5$ & $x$ & 22.73 & 38.42 & $x$ & 219.1 & $x$ \\
\hline 1995 & $1,654.9$ & $x$ & $7,656.7$ & $x$ & 22.68 & 72.96 & $x$ & 337.6 & $x$ \\
\hline 1996 & $3,294.2$ & $x$ & $11,463.5$ & $x$ & 22.61 & 145.71 & $x$ & 507.1 & $x$ \\
\hline 1997 & $7,027.4$ & $x$ & $25,689.1$ & $x$ & 22.55 & 311.69 & $x$ & $1,139.4$ & $x$ \\
\hline 1998 & $10,324.5$ & $x$ & $37,257.9$ & $x$ & 22.50 & 458.81 & $x$ & $1,655.7$ & $x$ \\
\hline 1999 & $18,125.5$ & $x$ & $55,479.4$ & $x$ & 22.46 & 807.08 & $x$ & $2,470.4$ & $x$ \\
\hline 2000 & $25,288.8$ & $10,485.5$ & $81,275.3$ & $33,699.0$ & 22.44 & $1,127.19$ & 467.37 & $3,622.7$ & $1,502.1$ \\
\hline 2001 & $33,817.8$ & $12,129.3$ & $118,327.2$ & $42,440.1$ & 22.41 & $1,509.16$ & 541.28 & $5,280.5$ & $1,893.9$ \\
\hline 2002 & $43,867.4$ & $12,562.6$ & $152,630.0$ & $43,709.7$ & 21.68 & $2,023.80$ & 579.57 & $7,041.5$ & $2,016.5$ \\
\hline 2003 & $51,363.2$ & $12,492.0$ & $198,761.1$ & $48,340.4$ & 21.57 & $2,380.75$ & 579.02 & $9,212.8$ & $2,240.6$ \\
\hline 2004 & $55,819.7$ & $14,073.5$ & $248,747.6$ & $62,715.3$ & 21.45 & $2,602.09$ & 656.05 & $11,595.6$ & $2,923.5$ \\
\hline 2005 & $59,010.9$ & $16,048.2$ & $290,488.8$ & $78,999.4$ & 21.32 & $2,767.91$ & 752.74 & $13,625.4$ & $3,705.5$ \\
\hline 2006 & $63,340.8$ & $18,730.5$ & $347,004.3$ & $102,612.4$ & 21.19 & $2,988.65$ & 883.77 & $16,373.0$ & $4,841.6$ \\
\hline 2007 & $82,324.3$ & $22,803.3$ & $418,257.9$ & $115,854.5$ & 20.88 & $3,942.17$ & $1,091.96$ & $20,028.7$ & $5,547.8$ \\
\hline 2008 & $109,795.1$ & $27,545.2$ & $524,388.7$ & $131,557.6$ & 20.54 & $5,345.99$ & $1,341.19$ & $25,532.8$ & $6,405.6$ \\
\hline 2009 & $147,329.1$ & $34,832.9$ & $510,522.8$ & $120,702.4$ & 20.37 & $7,233.56$ & $1,710.23$ & $25,065.6$ & $5,926.2$ \\
\hline 2010 & $194,459.2$ & $43,383.5$ & $533,881.1$ & $124,598.8$ & 20.25 & $9,604.44$ & $2,142.73$ & $26,368.7$ & $6,154.0$ \\
\hline 2011 & $223,268.0$ & $51,686.0$ & $565,097.2$ & $130,818.6$ & 20.15 & $11,081.59$ & $2,565.36$ & $28,047.8$ & $6,493.0$ \\
\hline 2012 & $240,842.6$ & $54,382.2$ & $586,681.5$ & $132,472.6$ & 20.06 & $12,006.00$ & $2,710.95$ & $29,246.1$ & $6,603.8$ \\
\hline 2013 & $267,150.9$ & $59,569.4$ & $637,583.1$ & $142,168.5$ & 19.99 & $13,367.03$ & $2,980.58$ & $31,901.8$ & $7,113.5$ \\
\hline 2014 & $295,655.5$ & $65,963.6$ & $666,637.3$ & $148,733.3$ & 19.91 & $14,850.66$ & $3,313.33$ & $33,484.9$ & $7,470.8$ \\
\hline
\end{tabular}

*the euro currency was officially adopted on December 16th,1995, while the currency itself penetrated on international markets as of January 1st, 1999, replacing the so-called European monetary unit

From this perspective, the evolution of public debt/inhabitant, in Romania, in the period 1990 - 2014, is shown in the chart below, as follows ${ }^{34}$ :

\footnotetext{
${ }^{34}$ Dascălu D., Ungureanu M.D., Considerations regarding the analyses of public debt in the current economic context, both national and international level, International Conference on Economic Sciences and Business Administration, 2021 noiembrie 2015
} 


$$
\begin{aligned}
& \text { (online) = ISSN } 2285-3642 \\
& \text { ISSN-L = 2285 - } 3642
\end{aligned}
$$

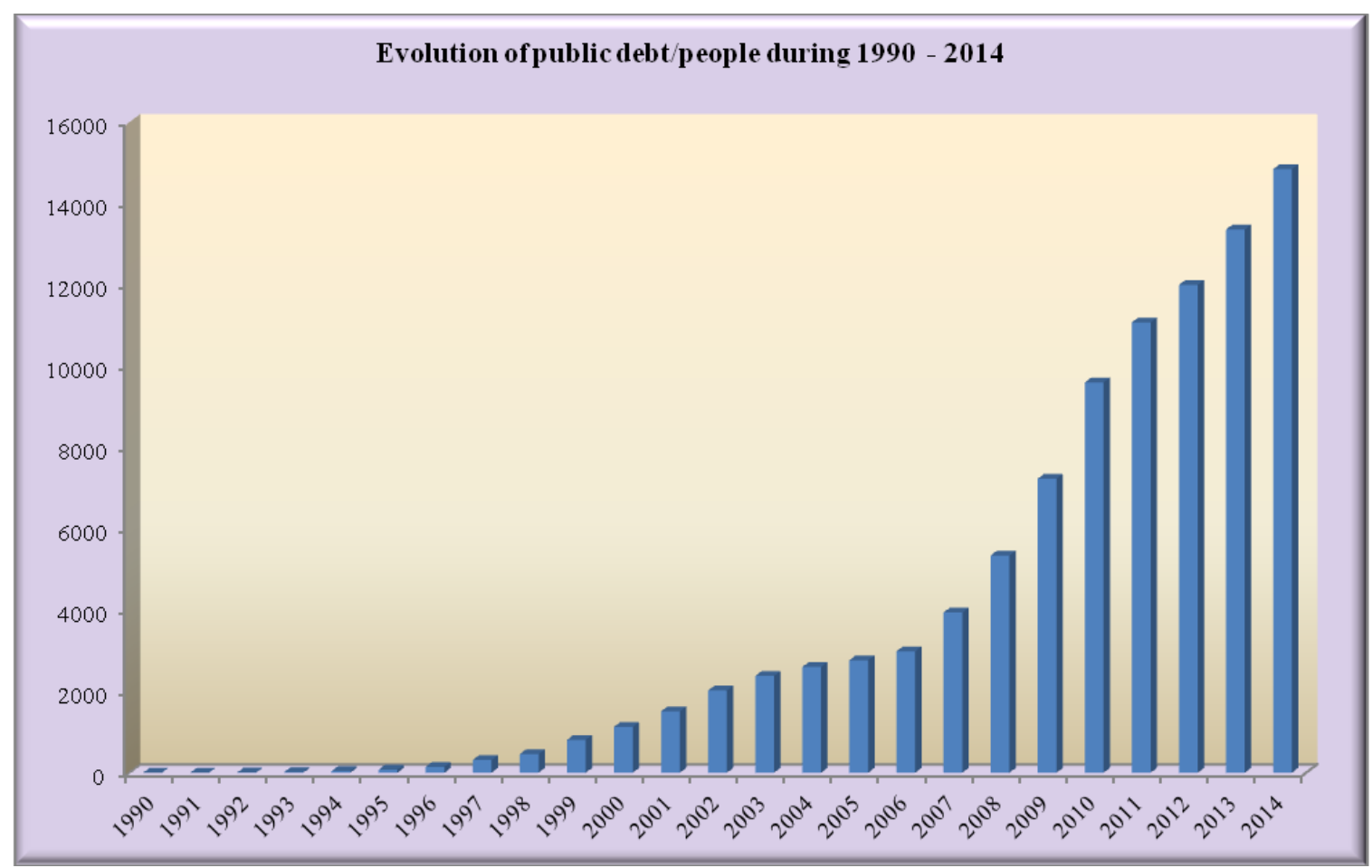

Figure 5: Evolution of public debt/inhabitant, in the period $1990-2014$

Source: EUROSTAT, http://eur-lex.europa.eu/, the National Statistics Institute of Romania, http://www.insse.ro/cms/

As it can be noted on the overall analysed period, the population of Romania had a downward trend, so that at the end of 2014 there were 19.19 million inhabitants, by $\mathbf{1 7 . 3 \%}$ less than the 23.21 million inhabitants recorded in 1990.

In this context, with the Romanian population permanently decreasing, while the volume of the country's public debt increased on a continual, there follows that the population indebtedness had an alert rhythm, reaching at the end of 2014 the value of 14,850.66 lei/inhabitant, which represents an increase by 495,022 times as compared to the level of 0.03 lei/inhabitant recorded in 1990.

The above chart, an analysis of public debt in euro/inhabitant in the period 2000-2014 (the euro penetrated international markets on 01.01.1999), shows that, by the end of 2014, it had a higher level as compared to 2000, while the one expressed in lei/inhabitant increased by $\mathbf{1 3 . 1 7}$ times, from 1,127.2 lei/inhabitant in 2000 to 14,850.66 lei/inhabitant in 2014.

The indicator GDP/inhabitant, in the period 2000-2014, had the same ascendant trend too, and at the end of 2014 was 7,470.8 euro/inhabitant, respectively $\mathbf{5 . 0}$ times more as compared to the level of 1,502.1 euro/inhabitant in 2000.

The conclusion of the above is that the indicator public debt/inhabitant had an accentuated growth as compared to the indicator GDP/inhabitant, Romania having major gaps in relation to the average level of 


\author{
(online) = ISSN $2285-3642$ \\ ISSN-L = 2285- 3642 \\ Journal of Economic Development, Environment and People \\ Volume 4, Issue 4, 2015 \\ URL: $\underline{\text { http://jedep.spiruharet.ro }}$ \\ e-mail: office jedep@spiruharet.ro
}

EU member states (the most edifying one in this respect being the GDP/inhabitant, assessed at the purchase power parity) ${ }^{35}$.

In the instance of the GDP/inhabitant, an indicator measuring economic activity, there are significant gaps among member states. In 2014, the GDP/inhabitant, expressed in the purchase power standard, varied between $\mathbf{4 5 \%}$ of the EU average, in the instance of Bulgaria and $\mathbf{2 6 3 \%}$ in Luxenbourg, Romania being on the last but one place in the EU, with a $\mathbf{5 4 \%}$ of the EU average ${ }^{36}$.

\title{
4. Conclusions
}

In order to maintain public debt at an acceptable level, it is necessary that the economy of Romania focuses efforts and financial resources to enhance the gross domestic product, by developing both the industrial sector through investment in intelligent technologies, which would generate added value, and through the agricultural sector (ecological agriculture), but also by developing constructions and services for population.

Even though from the point of view of public debt and of the deficit weight in the GDP, Romania is under the limits provided in the Maastricht Treaty and among the first countries in EU as to the standard of living, a significant gap is found in relation to other EU member states, our country holding the last but one place.

The increase of gross domestic product may be reached by abating taxation pressure over economy, especially over the productive sector of all economic branches, as well as by increasing the collection degree of taxes and fees, which can generate financial resources, funds which need to be oriented with priority towards investment making in the production sector of the Romanian economy.

From this perspective, the openness of Romanian economy shall be influenced in its evolution only by the exports volume, which, in turn, shall depend on the variations of the demand and offer on international markets and on the gross domestic product dynamics.

Economic openness is one of the actual convergence criteria, while actual convergence is obtained by sustained macro-economic policies. The statute as a member state of a monetary union triggers the opening degree of the economy by 10-26 percents, which in turn influences the dynamics of the GDP ${ }^{37}$.

In this respect, we consider that the moment Romania fulfils the economic growth conditions, it will benefit from acquiring the statute of a member state of the European Monetary Union, which will result in

\footnotetext{
${ }^{35}$ Financial Audit Report on the Public Debt Annual General Account for the year 2014 at the Ministry of Public Finances, www.curteadeconturi.ro/

${ }^{36}$ Financial Audit Report on the Public Debt Annual General Account for the year 2014 at the Ministry of Public Finances, www.curteadeconturi.ro/

37 The Theory "Optimum currency areas (OCA)" - (McKinnon, 1963), in which the economy openness degree is mentioned as an important convergence criteria
} 


\author{
(online) = ISSN $2285-3642$ \\ ISSN-L = 2285- 3642 \\ Journal of Economic Development, Environment and People \\ Volume 4, Issue 4, 2015 \\ URL: $\underline{\text { http://jedep.spiruharet.ro }}$ \\ e-mail: office jedep@spiruharet.ro
}

an enhancement of the country's economic opening degree and which will influence the gross domestic product dynamics.

Furthermore, the GDP growth, the increase of exports volume and the diminishing of imports shall result both in the increase of the international (foreign currency) reserve of the country and in the enhancement of the capacity to reimburse external funds borrowed on the capital markets and from international financial and banking and non-banking institutions (IMF, EIB, the World Bank, the Bank of Japan) as well as the diminishing of the economy need to borrow funds.

\title{
5. References:
}

[1] Bîrzea Cezar, European Union policies and institutions, Corint Publishing House, Bucharest, 2001

[2] Dascălu D., Datoria publică, reglementări și administrare in România (Public Debt, Regulations and Management in Romania), Editura Didactică și Pedagogică RA, Bucharest, 2008

[3] Dascălu D., Ungureanu M.D., Considerations regarding the analyses of public debt in the current economic context, both national and international level, International Conference on Economic Sciences and Business Administration, 20-21 noiembrie 2015

[4] Gheorghe D. Bistriceanu, Lexicon de finanţe-bănci-asigurări (Finances-banks-insurances Lexicon), Vol. II, Editura Economică, Bucharest, 2001

[5] Harold M. Groves, Financing Government, sixth edition, Holt, Rinehart and Winston, New York, Chicago, San Francisco, 1964

[6] Kouvertaris George, Moschonas Andreas (co-editors), The impact of the European Integration, political, sociological and economic changes, PRAGER, Westport, Connecticut, London, 1996

[7] McKinnon, The Theory "Optimum currency areas (OCA)", 1963, in which the economy openness degree is mentioned as an important convergence criteria

[8] Mekson M.H., Albert M., Khedouri F., Management, Third Edition, Harper-Row, Publisher, New York, 1995

[9] Treaty on European Union, published in Official Journal C 191 of 29 July 1992

[10] National Bank of Romania - Report on financial stability 2012, drafted by the - the Directorate for Financial Stability

[11] Ungureanu M.D. - Politici şi instituţii financiar-bancare europene, Editura Universitară, București, 2015

[12] Văcărel I. et al, Finanţe publice (Public Finances), second edition, Editura Didactică şi Pedagogică - Bucharest, 2008

[13] William J. Shultz, C. Lowell Harriss, American Public Finance, sixth edition, New York, 1954

\section{Websites:}

http://eur-lex.europa.eu/, the Maastricht Treaty on European Union 


\author{
(online) $=$ ISSN $2285-3642$ \\ ISSN-L = $2285-3642$ \\ Journal of Economic Development, Environment and People \\ Volume 4, Issue 4, 2015 \\ URL: http://jedep.spiruharet.ro \\ e-mail: office jedep@spiruharet.ro
}

http://ec.europa.eu/eurostat/documents

http://insse.ro, National Institute for Statistics

http://curteadeconturi.ro, Romanian Court of Accounts 